\title{
Rebranding LPP TVRI Melalui Logo Baru
}

\author{
Asep Soegiarto, Febby Alpionita \\ D III Hubungan Masyarakat, Fakultas Ilmu Sosial, Universitas Negeri Jakarta \\ Email: asep-sugiarto@unj.ac.id, Fby.alpio@gmail.com \\ Diterima 20 November 2019 / Disetujui 24 Desember 2019
}

\begin{abstract}
Rebranding process undertaken by LPP TVRI through its creation of new logo has been undisclosed, specifically to millennials. This research aims to perceive the information about the objective, process, and as well to analyze the impact of rebranding process through the new logo. This research utilizes a main concept about rebranding process in accordance to Ahonen, M (2008) which comprises of four stages, namely analyzing, planning, implementation, and evaluation. The method used is descriptive qualitative research. The technique used is intrinsic study case supported by data collection technique by conducting an in-depth interview, observation, and literature study. One key interviewee and four other interviewees are chosen using purposive technique. The result of this research shows that the objective of rebranding of LPP TVRI by creating a new logo is to mobilize the public perception to a positive image of corporate identity. The new logo-rebranding attempt is consisted of four stages, first is analyzing to know the state of affair of the corporate. Second, it takes planning which ensues two strategies. They are re-positioning, which it used to be merely a single platform and turns out it becomes a media that unites the multiplatform, and re-design of TVRI logo with the assistance of DMID brand consultant service. Third, implementation that can be evidenced through a show called New Logo Launching TVRI. Fourth, it ends with evaluation which has not done completely yet. The aftermath of new logo-rebranding process is to create a betterment of TVRI image, escalates the rating and numbers of audience, performance, and public perceptions. The conclusion of this research is the implementation attempted by TVRI by launching a brand-new logo is inefficacious, it hasn't reached to all levels of population. The suggestion offered by this research is TVRI to directly involve millennials as they are the main targets of the corporate brand acknowledgement. Other than that, corporate is advised to execute a publication strategy through social media with impressive and consistent contents.
\end{abstract}

Keywords: Rebranding; Image; Logo

\begin{abstract}
ABSTRAK
Proses rebranding yang dilakukan oleh LPP TVRI melalui penciptaan logo baru telah diciptakan, khususnya untuk milenium. Penelitian ini bertujuan untuk memahami informasi tentang tujuan, proses, dan juga untuk menganalisis dampak proses rebranding melalui logo baru. Penelitian ini menggunakan konsep utama proses rebranding sesuai dengan Ahonen, M (2008) yang terdiri dari empat tahap, yaitu menganalisis, merencanakan, mengimplementasikan, dan mengevaluasi. Metode yang digunakan adalah penelitian kualitatif deskriptif. Teknik yang digunakan adalah studi kasus intrinsik yang didukung oleh teknik pengumpulan data dengan melakukan wawancara mendalam, observasi, dan studi literatur. Key informan satu orang dan empat orang informan yang diwawancarai dipilih menggunakan teknik purposive sampling. Hasil penelitian ini menunjukkan bahwa tujuan rebranding LPP TVRI dengan membuat logo baru adalah memobilisasi persepsi publik menjadi citra
\end{abstract}


positif identitas perusahaan. Upaya logo-rebranding baru terdiri dari empat tahap, pertama adalah menganalisis untuk mengetahui keadaan bisnis perusahaan. Kedua, dibutuhkan perencanaan yang menghasilkan dua strategi. Mereka memposisikan ulang, yang dulunya hanya menjadi platform tunggal dan ternyata menjadi media yang menyatukan multiplatform, dan mendesain ulang logo TVRI dengan bantuan layanan konsultan merek DMID. Ketiga, implementasi yang bisa dibuktikan melalui acara yang disebut New Logo Launching TVRI. Keempat, diakhiri dengan evaluasi yang belum sepenuhnya dilakukan. Hasil dari proses rebranding logo yang baru adalah untuk menciptakan perbaikan citra TVRI, meningkatkan peringkat dan jumlah audiens, kinerja, dan persepsi publik. Kesimpulan dari penelitian ini adalah implementasi yang dicoba oleh TVRI dengan meluncurkan logo baru tidak efisien, belum mencapai semua tingkat populasi. Saran dalam penelitian ini adalah TVRI untuk secara langsung melibatkan milenium karena mereka adalah target utama dari pengakuan merek perusahaan. Selain itu, perusahaan disarankan untuk menjalankan strategi publikasi melalui media sosial dengan konten yang mengesankan dan konsisten.

Kata kunci: Citra; Logo; Rebranding

\section{PENDAHULUAN}

Perkembangan pertelevisian di dunia sejalan dengan kemajuan teknologi elektronik. Penemuan dasar televisi pada waktu itu terus berkembang hingga akhirnya ditemukan pesawat televisi seperti yang dikenal sekarang. Untuk pertama kalinya gambar televisi mulai terlihat tahun 1920 di Amerika Serikat. Siaran televisi di Indonesia dimulai pada tahun 1962. Walaupun pada saat itu kondisinya masih siaran televisi hitam putih namun masyarakat Indonesia sudah merasa disuguhi tontonan yang memukau.

Dewasa ini perusahaan stasiun TV berkembang pesat. Awalnya Indonesia hanya mempunyai 11 stasiun TV, namun saat ini sudah melebihi dari jumlah tersebut dan didominasi oleh TV swasta. Diantara sebelas stasiun TV tersebut, TVRI menjadi satusatunya stasiun TV nasional yang hingga saat ini masih terus aktif dan semakin melakukan perkembangan.

Peran TVRI sebagai TV Negara Republik Indonesia dan juga menjadi stasiun TV pertama di Indonesia, tapi tak bisa dipungkiri bahwa image yang tertanam di benak masyarakat saat ini tentang TVRI tidak terlepas dari anggapan "stasiun TV yang tidak kekinian". Seperti yang dikutip dalam wawancara penulis dengan Maimun Hasballah sebagai Kepala Subbagian Kelembagaan, Hukum, dan Humas LPP TVRI pada Senin, 13 Mei 2019, pukul 14.06 WIB, yang mengaku bahwa masih adanya anggapan TVRI dikenal sebagai TV yang masih jadul, monoton, acaranya tidak menarik, tidak milenial, serta tidak bisa bersaing dengan TV-TV swasta yang ada di Indonesia.

Saat ini zaman sudah berubah ke arah modern, dengan segala kecanggihan teknologi sudah banyak muncul perusahaan stasiun TV di Indonesia. Stasiun TV tersebut memiliki keunikan dan karakteristiknya masing-masing sebagai identitas perusahaannya. 
Kini perusahaan stasiun televisi berlomba-lomba memamerkan produk ataupun jasa yang mereka miliki dengan sekaligus memperkenalkan merek (brand) perusahaan kepada masyarakat. Brand sebagai identitas perusahaan, pembeda dengan perusahaan lain, dan representasi dari kualitas, strategi, dan positioning. Ketatnya persaingan perusahaan dalam stasiun TV, perkembangan informasi dan teknologi yang semakin maju dan pesat, perubahan perilaku konsumen, serta pencapaian tujuan yang efektif dan efisien menunjukkan pentingnya kekuatan brand pada suatu perusahaan.

Setelah memiliki identitas merek (brand) yang kuat bagi layanan yang diberikan, maka branding pun sangat perlu dilakukan untuk membentuk persepsi positif di mata khalayak. Branding sebagai alat komunikasi dalam mempromosikan identitas produk, jasa, dan perusahaan termasuk dalam mempromosikan LPP TVRI dalam upaya menghadapi persaingan dan perubahan, serta langkah untuk menciptakan citra bagi perusahaan.

LPP TVRI mencoba melakukan proses rebranding sebagai usaha untuk membentuk identitas baru dalam upaya menghadapi persaingan dan perubahan serta membentuk citra positif di mata publik. Proses rebranding TVRI ini dilakukan secara bertahap, berdasarkan data hasil riset dan terus dilakukan evaluasi untuk pemecahan masalah. Dimana tujuan akhir dalam proses rebranding ini adalah dalam rangka pencapaian visi misi perusahaan. Dimana visi dan misi baru TVRI yaitu menjadi stasiun TV yang berkelas dunia.

Proses rebranding yang dilakukan salah satunya melalui perubahan identitas perusahaan, yaitu logo. Penulis memfokuskan melakukan penelitian ini pada perubahan logo yang dilakukan, mengutip Lia Delina (2019) mengatakan bahwa perubahan pada logo ini menjadi hal yang paling mencolok dan banyak dibicarakan pada proses rebranding yang dilakukan, karena untuk pertama kali pula proses rebranding logo TVRI ini menggunakan jasa DMID sebagai brand consultant.

TVRI kemudian menggelar acara Launching Logo Baru TVRI pada tanggal 29 Maret 2019 di Auditorium LPP TVRI Pusat. Acara ini menjadi momentum untuk mengenalkan identitas barunya, terutama pada kalangan milenial. Namun setelah pelaksanaan launching logo baru dari hasil proses rebranding ini, ternyata belum diketahui oleh semua kalangan terutama kalangan milenial yang menjadi target penonton TVRI . Terbukti berdasarkan hasil wawancara penulis dengan salah satu kaum milenial pada Kamis, 18 Mei 2019, Tazkia Mayda Syarief mengatakan bahwa tidak mengetahui bila TVRI melakukan rebranding logo baru. 
Dengan demikian hal ini menjadi perhatian utama bagi TVRI, bahwa ternyata proses rebranding ini banyak masyarakat yang belum sadar dengan adanya perubahan logo sehingga hal ini juga belum mencapai tujuan adanya peningkatan citra terhadap TVRI. Berkaitan dengan hal ini juga menjadi perhatian utama bagi PR TVRI sebagai tim yang berperan dalam proses rebranding ini. Artinya proses publikasi rebranding serta usaha menciptakan citra positif terhadap perusahaan belum berjalan maksimal. Dimana peran PR dalam proses rebranding juga sangat berpengaruh. Menurut Ruslan (seperti dikutip Dini Safitri, 2015), Public Relations mempunyai peran ganda, dimana PR di satu pihak berupaya menjaga citra baik terhadap lembaga ataupun organisasi yang diwakilinya, namun di lain pihak, ia harus berhadapan dengan berbagai situasi yang kurang menguntungkan, seperti opini publik yang negatif hingga krisis kepercayaan dan citra perusahaan.

Dalam menjalankan peran PR untuk menjaga dan meningkatkan citra atau image perusahaan, maka seorang PR penting terlibat dalam proses rebranding untuk dapat menjalankan strategi komunikasi perusahaan. Rebranding tidak semata-mata dilakukan hanya untuk mengubah identitas brand saja, tetapi ada tujuan-tujuan yang diharapkan oleh perusahaan. Sehingga rebranding harus dipikirkan secara matang, untuk itu diperlukan model proses rebranding yang dapat dijadikan sebagai acuan bagi perusahaan dalam melakukan rebranding.

Penelitian yang dilakukan penulis dapat ditarik tiga konsep besar yang membahas penelitian ini secara keseluruhan, diantaranya yaitu rebranding, citra perusahaan, dan corporate identity. Terdapat beberapa penelitian terdahulu yang juga membahas tentang tiga konsep tersebut, diantaranya sebagai berikut.

Salah satu penelitian yang sudah dilakukan yaitu berjudul "Proses Rebranding Mal Grand Indonesia Oleh Departemen Marketing Communication PT Grand Indonesia” yang dilakukan oleh Fitria Adianti Putri, Suwandi Sumartias, dan Diah Fatma Sjoraida (2018). Penelitian ini menjelaskan bahwa persaingan bisnis dibidang industri ritel saat ini yang semakin ketat, salah satunya adalah shopping mall yang menjadi primadona ritel di tanah air. Mal Grand Indonesia dikenal sebagai pusat pembelanjaan telah membawa Grand Indonesia ke dalam bisnis ritel terkemuka dan salah satu mal terbesar di Indonesia. Mal Grand Indonesia juga melakukan langkah perubahan baru yang lebih baik yaitu dengan melakukan rebranding. Diketahui alasannya adalah untuk penyegaran kembali dan perubahan positioning perusahaan di mata publik. Proses rebranding Mal Grand Indonesia dilakukan melalui beberapa tahap, yaitu repositioning, renaming, redesigning, dan 
relaunching. Dari hasil penelitian diketahui bahwa pada tahap re-launching pelaksanaannya kurang optimal, Grand Indonesia tidak mempublikasikan secara eksplisit kepada publik bahwa telah melakukan proses rebranding.

Publik dan media dituntut untuk mengerti dengan sendirinya bahwa Grand Indonesia telah mengubah konsep malnya. Tentunya, ini menimbulkan kesenjangan pemahaman antara Grand Indonesia dengan publiknya. Diketahui alasan diangkatnya masalah ini menjadi penelitian karena banyaknya publik yang juga tidak mengetahui bahwa adanya proses rebranding yang dilakukan. Sehingga tujuan dilakukannya penelitian ini untuk mengetahui bagaimana proses repositioning, renaming, redesigning, dan relaunching dari segala aspek perubahan yang dilakukan Grand Indonesia. Sedangkan penelitian yang dilakukan penulis hanya fokus untuk mengatahui bagaimana proses rebranding yang dilakukan LPP TVRI dengan perubahan logo barunya hingga dapat diketahui publik.

Penelitian lainnya berjudul "Pengaruh Penggunaan Media Internal Portal PT Dirgantara Indonesia Terhadap Citra Perusahaan" yang dilakukan oleh Ziko Pasaribu dan Diah Agung E (2015). Penelitian ini membahas tentang pengaruh penggunaan media internal portal PT Dirgantara Indonesia terhadap citra perusahaan. Diawali dengan latar belakang dimana PT Dirgantara pernah mengalami kondisi krisis ekonomi tahun 1998, hingga munculnya masalah pemberitaan negatif di media massa setelah PHK besar-besaran yang dilakukan PT Dirgantara Indonesia karena pemberhentian aliran dana oleh pemerintah semakin memperburuk pandangan dan persepsi karyawan serta masyarakat terhadap PT Dirgantara Indonesia. Namun, PT Dirgantara Indonesia berhasil menanggulangi dan mengatasi pemberitaan negatif tersebut dengan bangkit kembali menjalin kepercayaan pemegang saham dan karyawan sehingga mampu meningkatkan produktivitas perusahaan. Keberhasilan ini tidak terlepas dari peran public relation PT Dirgantara Indonesia yang memanfaatkan teknologi intranet sebagai salah satu media komunikasi internal perusahaan. Melalui intranet ini diharapkan dapat membentuk kembali citra positif baik dari eksternal perusahaan maupun internal, terutama karyawan terhadap PT Dirgantara. Terbukti dengan hasil penelitian yang menunjukkan bahwa penggunaan media internal Portal PT Dirgantara Indonesia dapat memengaruhi citra perusahaan dalam persepsi karyawan.

Persamaan penelitian ini dengan penelitian penulis adalah terdapat peran PR dalam tujuan membentuk citra positif perusahaan. Proses rebranding yang dilakukan LPP TVRI juga memiliki tujuan akhir untuk dapat membentuk citra positif dari publik terhadap performa TVRI saat ini. Perbedaannya terdapat pada penelitian ini membahas pembentukan 
citra perusahaan melalui media komunikasi internal, sedangkan penulis membahas pembentukan citra perusahaan melalui rebranding logo baru. Serta penelitian ini menggunakan metode kuantitatif untuk mengetahui besar pengaruh penggunaan media internal portal PT Dirgantara Indonesia terhadap citra perusahaan. Sedangkan penulis melalui metode kualitatif untuk mengetahui bagaimana dampak rebranding logo baru terhadap citra perusahaan.

Penelitian dengan judul "Pengaruh Logo Baru PT. Telkom, Tbk Terhadap Citra Perusahaan” yang ditulis oleh Febriansyah, Nuzul Inas Nabila (2014). PT. Telkom yang menjadi objek penelitian ini melakukan rebranding melalui logo perusahaannya, alasan Telkom melakukan rebranding dikarenakan menyesuaikan dengan kondisi lingkungan yang ada. Perkembangan teknologi dan ketatnya persaingan bisnis telekomunikasi juga mendorong untuk melakukan perubahan. Sehingga dipilih strategi manajemen perusahaan agar dapat tetap eksis, maka perusahaan perlu memperbarui identitasnya, salah satunya melalui logo. Penelitian ini bertujuan untuk mengetahui sejauh mana logo baru dapat memengaruhi citra perusahaan.

Penelitian ini menggunakan pendekatan kuantitatif. Hasil analisis data yang diperoleh perubahan logo (rebranding) berpengaruh secara signifikan terhadap citra perusahaan di PT Telkom di Bandar Lampung. Penelitian yang dilakukan memiliki persamaan pembahasan mengenai konsep rebranding melalui corporate identity, yaitu logo. Perbedaan penelitian ini dengan yang dilakukan penulis adalah pada tujuan penelitian. Penelitian ini ingin melihat seberapa besar pengaruh rebranding logo terhadap citra perusahaan PT Telkom. Sedangkan penulis melakukan penelitian ini bertujuan untuk mengetahui apa saja dampak dari proses rebranding melalui logo baru terhadap TVRI.

Penulis juga membandingkan dengan penelitian lainnya, seperti penelitian yang berjudul "Strategi Rebranding Zora Radio" yang dilakukan oleh Dini Safitri Istiqomah. Penelitian ini memiliki persamaan, yaitu dalam studi kasus rebranding pada media massa Indonesia. Penulis melakukan penelitian pada media televisi yaitu TVRI, sedangkan penelitian ini dilakukan pada Zora Radio yang menjadi objek penelitian. Di mana, latar belakang dilakukan proses rebranding pada objek penelitian ini juga sama karena disebabkan oleh tingginya persaingan industri bisnis serta dalam usaha merebut minat pasar/konsumen. Persamaan lainnya pada metode penelitian yang digunakan yaitu kualitatif, namun fokus penelitian ini adalah untuk mengetahui bagaimana strategi rebranding Zora Radio melalui 3 tahap utama yaitu tahap perencanaan, implementasi, dan 
evaluasi. Sedangkan fokus penelitian penulis salah satunya adalah untuk mengetahui bagaimana proses rebranding LPP TVRI melalui logo baru berdasarkan teori yang digunakan menurut Ahonen, M. (2008), yaitu melalui tahap analyzing, planning, implementation, dan evaluation. Hasil dari penelitian ini menunjukkan bahwa strategi rebranding Zora Radio dilakukan melalui 3 tahap utama, dan dapat dikatakan sudah menarik perhatian banyak pihak terutama pendengar dari segmentasi anak muda yang menjadi pangsa pasar utamanya dalam proses rebranding ini. Tujuan ini dapat tercapai karena setiap elemen yang berubah disesuaikan dengan target pasarnya saat ini, serta strategi yang dilakukan pada tahap implementasi, Zora Radio mencoba mensosialisasikan hasil rebranding ke pihak internal dan eksternal dengan menggelar event-event menarik, melibatkan secara langsung komunitas anak muda, serta menjalin kerja sama endorsement dengan pihak ketiga. Hal ini dilakukan juga dalam rangka untuk mengenalkan keberadaan brand perusahaan kepada khalayak.

Merujuk pada penelitian terdahulu lainnya, dengan judul "Strategi Marketing Public Relations Dalam Rebranding HSBC Indonesia Untuk Membentuk Brand Awareness", penelitian ini dilakukan oleh Prasetya Yoga Santoso dan kawan-kawan pada tahun 2018. Latar belakang penelitian ini didasari oleh perubahan dan proses integrasi dari Bank Ekonomi menjadi Bank HSBC Indonesia yang dirasa perlu untuk dipublikasikan secara luas kepada publik. Proses rebranding yang dilakukan HSBC Indonesia tidak sepenuhnya perubahan secara visual, namun juga pada positioning perusahaan. Tujuan utama HSBC Indonesia melakukan rebranding untuk membentuk brand awareness dalam benak publiknya. Sehingga tujuan dilakukannya penelitian ini sama dengan tujuan penelitian penulis, yaitu untuk mengetahui bagaimana proses rebranding yang dilakukan yang diteliti melalui metode kualitatif.

Penelitian ini menggunakan teori marketing Kotler dan Armstrong (2011:49) yang memaparkan pemahaman tentang market segmentation, market targeting, dan market positioning. Serta juga terdapat teori marketing Public Relations Harris dan Whalen (2006:7) yang menjelaskan bahwa terdapat peran PR untuk mendukung serta menggapai tujuan dari program marketing. Selain itu, untuk membangun kesadaran publik (awareness). Hasil dari rebranding pada elemen brand HSBC Indonesia terlihat pada logo, slogan, dan nama brand. Walaupun perubahan pada elemen brand ini tidak begitu signifikan, namun penelitian ini lebih menjelaskan bagaimana strategi publikasi yang dilakukan divisi Marketing dan PR HSBC dalam proses rebranding yaitu melalui 
engagement stakeholders. Hasil penelitian ini juga sama dengan hasil penelitian yang dilakukan penulis, bahwa proses rebranding ini memberikan dampak dengan terbentuknya brand awareness yang diharapkan perusahaan.

Menurut Lambkin (dikutip dari Donni Juni Priansa, 2017:269) Rebranding adalah upaya yang dilakukan oleh perusahaan atau lembaga untuk mengubah atau memperbarui sebuah brand yang telah ada agar menjadi lebih baik dengan tidak mengabaikan tujuan awal perusahaan, yaitu berorientasi profit. Rebranding tidak semata-mata dilakukan hanya untuk mengubah identitas brand saja, tetapi ada tujuan-tujuan yang diharapkan oleh perusahaan.

Menurut Ahonen, M. (2008) terdapat model proses dalam corporate rebranding, yaitu pada umumnya meliputi empat tahap. Tahap analyzing, pada tahap ini perusahaan harus benar-benar memahami situasi, hal yang ada dibalik rebranding, pengambilan keputusan, perubahan struktur perusahaan, strategi, serta performance perusahaan. Beberapa hal ini dianalisis secara teliti untuk memudahkan tahapan-tahapan selanjutnya. Selanjutnya tahap planning, pada proses ini perusahaan merencanakan elemen penting dari rebranding, yaitu re-positioning, re-naming, re-stucturing, dan re-design perusahaan. Kemudian tahap Implementation adalah proses ketika rencana direalisasi. Dalam konteks proses tindakan (action) hal ini juga mencakup aktivitas spesifik mengenai tim yang akan terlibat dan deadline waktu dari setiap program tersebut.

Bentuk pelaksanaan tahap implemantasi ini adalah perusahaan melakukan relaunching identitas baru serta mengenalkan brand baru dengan berbagai media yang ada, melalui advertising, workshop, online marketing, ataupun media lainnya. Dan terakhir, tahap evaluation. Meskipun disajikan terakhir, evaluasi bukanlah tahap akhir dari proses dalam manajemen Public Relations. Dalam praktiknya yang sebenarnya, evaluasi seringkali merupakan awal dari upaya baru. Pada tahap ini, perusahaan harus mengukur keberhasilan rebranding serta melihat kecenderungan apa yang terjadi selama proses berlangsung. Keberhasilan proses rebranding diukur melalui sejauh apa tujuan rebranding dapat dicapai. Oleh karena itu, dibutuhkan monitoring secara teliti untuk dapat mengevaluasi proses rebranding secara keseluruhan sehingga terlihat outcome yang dihasilkan melalui corporate brand baru.

Penelitian dengan judul Rebranding LPP TVRI Melalui Logo Baru yang dilakukan penulis ini memiliki tujuan untuk mengetahui lebih dalam dan mendapatkan gambaran deskriptif mengenai tujuan TVRI melakukan rebranding melalui logo baru, bagaimana 
proses rebranding yang dilakukan, serta bagaimana dampak dari proses rebranding tersebut. Dari penelitian ini diharapkan dapat bermanfaat untuk melengkapi penerapan teori bagi bidang akademis. Serta bermanfaat menambah wawasan bagi pembaca, dan dapat menjadi bahan evaluasi perusahaan.

\section{METODE PENELITIAN}

Penelitian ini menggunakan pendekatan kualitatif dengan metode penelitian deskriptif. Hal ini bertujuan untuk dapat melihat realitas sosial secara utuh dan mendalam serta menghasilkan data deskriptif dengan tujuan dapat menggambarkan secara sistematis fakta dan karakteristik realitas sosial yang diteliti. Teknik penelitian yang digunakan adalah studi kasus intrinsik. Dimana menurut Asfi Manzilati (2017) dalam penelitian studi kasus, peneliti menelusuri suatu aktivitas, proses, atau sekelompok individu secara spesifik sebagai fokus masalah dalam penelitian. Melalui teknik pengumpulan data dengan wawancara mendalam, observasi, dan studi kepustakaan.

Wawancara dilakukan dengan tipe depth interview dengan narasumber, wawancara juga dilakukan melalui telepon dan aplikasi whatsapp dengan narasumber. Observasi dilakukan langsung di LPP TVRI Pusat, Jl. Gerbang Pemuda No.8 Jakarta. Untuk studi kepustakaan dan dokumen melalui Majalah Monitor TVRI, dokumen Roadmap TVRI, data

dari bidang Puslitbang TVRI, serta sumber literatur kepustakaan. Informan dalam penelitian ini dipilih berdasarkan teknik purposive, yang terdiri dari satu orang key informan dan empat informan lainnya. Teknik analisis data dilakukan mulai dari tahapan pemaparan data, pengolahan data, temuan penelitian, hingga pembahasan hasil temuan. Serta penelitian ini menggunakan teknik triangulasi sumber sebagai uji keabsahan data.

\section{HASIL DAN PEMBAHASAN Hasil Penelitian}

Hasil penelitian ini didapatkan melalui proses wawancara yang dilaksanakan secara langsung dan mendalam dengan informan. Informan yang berhasil diwawancarai oleh peneliti secara intensif dalam penelitian ini berjumlah 5 orang. Semua data hasil penelitian ini diuraikan berdasarkan perumusan masalah yang menjadi fokus pertanyaan dalam penelitian. Dari hasil wawancara, penulis dapat merangkum mengenai tujuan, proses, dan dampak proses dari rebranding LPP TVRI melalui logo baru.

Tujuan yang ingin dicapai TVRI melakukan rebranding melalui logo baru untuk menunjukkan TVRI sebagai media pemersatu bangsa yang berlandaskan visi perusahaan 
yaitu menjadi world class public broadcasting. Dengan rebranding melalui logo baru ini juga ingin merepresentasikan semangat baru TVRI dalam melakukan perubahan yang lebih baik serta untuk mengubah persepsi masyarakat agar tercapai citra TVRI yang positif.

Proses rebranding LPP TVRI memerlukan waktu lama dan melewati beberapa tahapan. Perlu persiapan dan pemikiran secara matang mengenai kesiapan, baik segi internal maupun eksternal perusahaan. Dari hasil wawancara dapat diketahui bahwa proses rebranding ini melibatkan peran semua pihak di TVRI. Mulai dari Humas TVRI yang menjadi garda terdepan untuk mensosialisasikan implementasi rebranding baik kepada internal maupun eksternal TVRI, kemudian bidang Puslitbang yang melakukan riset dan analisis yang berguna sebagai bahan masukan kepada manajemen untuk mengambil kebijakan melakukan rebranding melalui logo baru ini. Serta TVRI bekerja sama dengan brand consultant yang berperan dalam melakukan assessment secara menyeluruh, men-design logo baru, serta memberikan suggestion yang tepat bagi TVRI dalam rangka rebranding.

\section{Model Proses Corporate Rebranding}

Menurut Ahonen,M. (2008) terdapat model proses dalam corporate rebranding, yaitu pada umumnya meliputi empat tahap, sebagai berikut. Tahap Analyzing, berdasarkan hasil penelitian diketahui hasil analisis kondisi yang TVRI hadapi yaitu kurangnya minat penonton karena konten yang kurang menarik dan didominasi oleh TV swasta, jumlah rating penonton yang lebih sedikit, serta banyaknya aset TVRI yang tidak terdengar lagi oleh publik dan sangat membutuhkan pembenahan produk. Hal ini menggambarkan bahwa hasil analisis TVRI melakukan rebranding melalui logo baru karena berawal dari kondisi dan performa TVRI yang monoton serta kurang mampu bersaing perusahaan TV lainnya.

Kedua, tahap planning pada proses ini perusahaan melakukan perencanaan terhadap elemen penting dari rebranding, yaitu re-positioning, re-naming, re-stucturing, dan redesign perusahaan. Berdasarkan hasil penelitian, dalam tahap ini TVRI hanya menjalankan 2 strategi utama dari proses rebranding, yaitu re-positioning dan re-design.

Ketiga, tahap implementation yang ditandai dengan munculnya logo baru, TVRI menggelar acara Launching Logo Baru TVRI yang di Auditorium LPP TVRI. Logo baru TVRI ini resmi dipublikasikan secara serentak pada hari Jumat tanggal 29 Maret 2019. Acara Launching Logo Baru TVRI ini sekaligus menjadi ajang bagi TVRI untuk mensosialisasikan serta publikasi secara langsung logo baru kepada pihak internal maupun ekternal. 


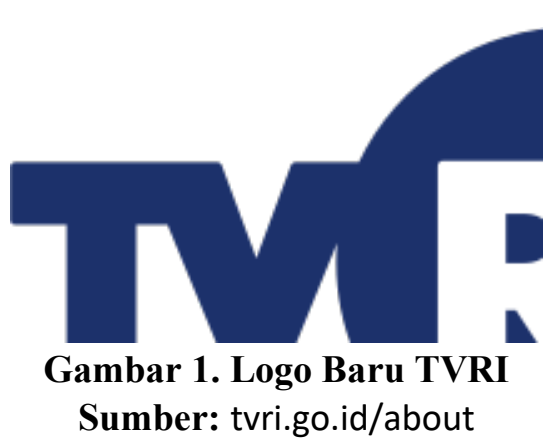

Logo baru TVRI mengandung makna yang menunjukkan TVRI sebagai media pemersatu bangsa yang akan memberikan konten program yang positif serta menjadi kebanggaan dari Indonesia menuju kelas dunia. Kemudian dari segi warna yang dipilih menunjukkan Indonesia sebagai negara kepulauan, sedangkan dari segi font yang digunakan menunjukkan TVRI sebagai media nasional yang kokoh, kuat, dan untuk menjaga konsistensi brand. Logo baru ini sudah diterapkan pada berbagai elemen ataupun kebutuhan corporate identity TVRI, di mana dalam implementasinya harus berpedoman pada standar rebranding logo yang sudah dibuat.

Keempat, tahap evaluation. Dalam pelaksanaan rebranding TVRI melalui logo baru ini belum dilakukan proses evaluasi secara keseluruhan. Walaupun belum dilakukan evaluasi secara keseluruhan, namun menurut bidang Humas proses rebranding TVRI melalui logo baru ini berjalan lancar. Begitu juga dari pihak brand consultant yang belum melakukan evaluasi secara formal namun tetap menjaga komunikasi rutin dengan pihak TVRI.

Hasil penelitian ini juga memberikan dampak dari proses rebranding TVRI melalui logo baru, mulai dari terbentuknya citra perusahaan yang positif, terbentuknya public trust, peningkatan rating jumlah penonton, performa dan kinerja TVRI yang semakin baik, serta adanya respon dan tanggapan positif dari masyarakat yang mengakibatkan peningkatan rating untuk TVRI. Dampak proses rebranding melalui logo baru ini juga ternyata sudah diketahui oleh beberapa kalangan milenial.

\section{Pembahasan}

Dalam penelitian ini, penulis ingin mengetahui bagaimana proses rebranding yang dilakukan oleh LPP TVRI melalui logo barunya. Penulis menggunakan teori utama yang dianalisis adalah model proses dari corporate rebranding menurut Ahonen,M. (2008), yaitu melalui tahapan analyzing, planning, implementation, dan evaluation. Dan menjawab 
tujuan dari penelitian ini dengan dirumuskan berdasarkan tiga rumusan masalah, yaitu untuk mengetahui tujuan, proses, dan dampak proses rebranding melalui logo baru.

Dari hasil penelitian diketahui bahwa tujuan LPP TVRI melakukan rebranding melalui logo baru ini dilatarbelakangi karena TVRI ingin menyelamatkan brand yang sudah jenuh dengan memperbaruinya menjadi lebih baik agar mencapai tujuan yang diinginkan perusahaan. Selain itu juga bertujuan mencapai citra perusahaan (corporate image) dalam benak konsumen. Di mana citra diawali dari identitas perusahaan (corporate identity) sebagai titik pertama yang tercermin melalui nama perusahaan, logo, company profile sebagai identitas fisik.

TVRI melakukan proses rebranding salah satunya pada identitas fisik perusahaan melalui perubahan logo. Logo merupakan suatu simbol yang di desain khusus sebagai identitas perusahaan pada suatu brand untuk bisa dikenali secara cepat oleh penggunanya atau masyarakat awam. Logo saat ini memainkan peran sentral untuk menaikkan citra perusahaan, karena logo dapat menunjukkan jati diri serta terkandung makna visi perusahaan (Mikael Sugianto dan Smitdev, 2011:29). Logo dan simbol ini dapat membantu konsumen untuk membangun persepsi tentang brand atau perusahaan. Sama halnya dengan yang dilakukan oleh TVRI yang melakukan rebranding melalui logo baru, tujuan yang ingin dicapai TVRI adalah menunjukkan TVRI sebagai media pemersatu bangsa yang berlandaskan visi perusahaan yaitu menjadi world class public broadcasting. Dengan rebranding melalui logo baru ini juga ingin merepresentasikan semangat baru TVRI dalam melakukan perubahan yang lebih baik serta untuk mengubah persepsi masyarakat agar tercapai citra TVRI yang positif.

Setelah menetapkan tujuan, dilanjutkan dengan proses rebranding yang dijalankan melalui empat tahapan utama. Tahap analyzing, di mana dilakukannya analisis untuk memahami kondisi dan situasi yang dihadapi perusahaan. Hasil analisis menyatakan bahwa TVRI kurang diminati penontonnya karena konten yang kurang menarik dan didominasi oleh TV swasta. Akhirnya TVRI memutuskan untuk melakukan rebranding melalui logo baru karena berawal dari kondisi dan performa TVRI yang monoton serta kurang mampu bersaing perusahaan TV lainnya. Sehingga dibutuhkan perubahan melalui logo yang agar dapat terlihat lebih fresh, dapat merepresentasikan semangat baru TVRI, dan melalui logo dapat menjadi icon sebagai media komunikasi universal.

Tahap planning pada proses ini perusahaan melakukan perencanaan terhadap elemen penting dari rebranding. Berdasarkan hasil penelitian, dalam tahap ini TVRI hanya 
menjalankan 2 strategi utama dari proses rebranding, yaitu re-positioning dan re-design. Repositioning adalah keputusan yang diambil perusahaan untuk membentuk posisi baru bagi perusahaan di benak konsumen, pesaing, dam pemilik kepentingannya (Ries and Trout dalam Muzellec, dkk, 2003). TVRI mengalami re-positioning yaitu menjadi media pemersatu bangsa yang multiplatform dari posisi sebelumnya hanya menjadi saluran pemersatu bangsa. Sedangkan re-design adalah proses perancangan kembali mengenai bentuk, tampilan, bobot, serta kontras yang baik dari sebuah logo perusahaan (Kadar Nurjaman dan Khaerul Umam, 2012). TVRI menjalankan proses re-design logo baru TVRI yang dikelola oleh DMID sebagai brand consultant. Dari hasil penelitian juga diketahui alasan TVRI menggunakan jasa konsultan karena TVRI menginginkan proses desain logo dikerjakan oleh ahlinya dengan pertimbangan dan perhitungan penuh, karena logo dinilai sebagai urat nadi perusahaan. Proses dan hasil desain logo baru TVRI ini berdasarkan hasil kordinasi kedua belah pihak.

Di tahap implementation, TVRI menggelar acara Launching Logo Baru yang di Auditorium LPP TVRI. Logo baru TVRI ini resmi dipublikasikan secara serentak pada hari Jumat tanggal 29 Maret 2019. Dan launching-nya logo baru ini juga dipublikasikan melalui media sosial TVRI. Kemudian dilanjutkan dengan mengadakan serangkaian event seru yang mengundang masyarakat sekitar mulai dari fun bike, fun walk, dan zumba. Kemudian implementasi logo baru ini juga diterapkan pada pencetakan, banner, spanduk, baliho dan melalui kegiatan off air lainnya, serta media sosial TVRI. Dalam tahap ini dilanjutkan dengan kegiatan sosialisasi yang dilakukan ke stasiun-stasiun daerah TVRI, khususnya untuk karyawan internal TVRI. Namun diketahui bahwa dalam rangkaian launching logo baru ini TVRI tidak mengundang ataupun melibatkan langsung kehadiran kalangan milenial, sehingga proses publikasipun tidak tercapai ke semua kalangan.

Terakhir, tahap evaluation. Dalam pelaksanaan rebranding TVRI melalui logo baru ini belum dilakukan proses evaluasi secara keseluruhan dikarenakan rebranding ini baru saja launching dan masih terhitung kurang dari setahun penerapannya sehingga saat ini masih difokuskan pada tahap penyamarataan implementasi dan sosialisasi kepada internal maupun eksternal TVRI. Walaupun belum dilakukan evaluasi secara keseluruhan, namun menurut bidang Humas proses rebranding TVRI melalui logo baru ini berjalan lancar dengan proses implementasi logo dan juga terlihat dengan semangat dan kesadaran karyawan internal TVRI yang merepresentasi makna dari logo tersebut. Begitu juga dari 
pihak brand consultant yang belum melakukan evaluasi secara formal namun tetap menjaga komunikasi rutin dengan pihak TVRI.

Proses rebranding TVRI melalui logo baru ini juga memberikan dampak yang baik, mulai dari terbentuknya citra perusahaan yang positif, terbentuknya public trust, peningkatan rating jumlah penonton, performa dan kinerja TVRI yang semakin baik, serta adanya respon dan tanggapan positif dari masyarakat mengenai corporate identity TVRI yang baru. Dampak proses rebranding melalui logo baru ini juga ternyata sudah diketahui oleh beberapa kalangan milenial. Hanya saja proses sosialisasi dan publikasi mengenai launching logo baru ini kurang melibatkan kehadiran dan minat kalangan milenial. Sehingga dari pihak penonton merasa bahwa keberhasilan dalam membentuk brand awareness dan juga citra positif perusahaan belum dikatakan optimal dan dirasa perlu perubahan yang terus berkelanjutan.

Dari pembahasan hasil penelitian tersebut dapat digambarkan bahwa tujuan proses rebranding LPP TVRI melalui logo baru ini dalam rangka membentuk brand awareness dan citra positif perusahaan, walaupun belum dapat dirasakan secara maksimal, namun usaha untuk berubah dan peningkatan dapat dilihat dari beberapa pencapaian yang diraih TVRI setelah melakukan rebranding. Hal ini menandakan hasil penelitian ini memenuhi tujuan dari penelitian ini. Namun perlu adanya perbandingan dengan temuan jurnal-jurnal sebelumnya guna menghasilkan temuan baru pada penelitian penulis.

Secara keseluruhan penulis dapat menarik kesimpulan dari beberapa jurnal penelitian sebelumnya yang membahas mengenai proses rebranding, logo sebagai corporate identity, maupun peran PR dalam membentuk citra perusahaan. Pada penelitian berjudul "Proses Rebranding Mal Grand Indonesia Oleh Departemen Marketing Communication PT Grand Indonesia" dapat ditemukan hasil penelitian bahwa tahap relaunching dari proses rebranding yang dilakukan terjadi secara implisit yang memfokuskan publikasi hanya pada internal Mal Grand Indonesia, sehingga publik pun kurang mengetahui proses rebranding yang terjadi. Hal ini sama dengan hasil penelitian yang penulis lakukan, bahwa proses re-launching logo baru TVRI yang tidak melibatkan kehadiran serta kerja sama dengan semua kalangan yang menjadi target penonton TVRI. Penelitian selanjutnya yang berjudul "Pengaruh Penggunaan Media Internal Portal PT Dirgantara Indonesia Terhadap Citra Perusahaan”. Penelitian ini menunjukkan bahwa peran praktisi PR dalam membentuk citra positif perusahaan juga dapat melalui penggunaan portal media internal, yaitu teknologi intranet. Hasil penelitian melalui pendekatan 
kuantitatif ini berhasil menunjukkan bahwa melalui media internal Portal PT Dirgantara Indonesia dapat memengaruhi citra perusahaan dalam persepsi karyawan.

Berbeda dengan penelitian yang berjudul "Pengaruh Logo Baru PT. Telkom, Tbk Terhadap Citra Perusahaan”. Penelitian ini menunjukkan bahwa perubahan logo baru sebagai corporate identity dapat memengaruhi citra perusahaan secara signifikan. Jadi melalui rebranding logo perusahaan, penelitian ini memiliki kesamaan dengan fokus penelitian yang penulis lakukan, serta membuktikan bahwa melalui logo juga dapat membentuk citra positif perusahaan. Penulis juga melakukan perbandingan dengan penelitian lainnya, dalam penelitian berjudul "Strategi Rebranding Zora Radio" dapat diketahui bahwa fokus penelitian tentang strategi rebranding yang dapat dilakukan melalui 3 tahap utama, yaitu perencanaan, implementasi, dan evaluasi.

Hasil penelitian juga menunjukkan strategi rebranding yang dilakukan dapat berhasil dalam mencapai tujuan perubahan segmentasi untuk menarik anak muda sebagai target utamanya dengan melakukan proses implementasi yang menarik, sesuai minat pasar, dan selalu melakukan evaluasi. Sama halnya dengan penelitian yang berjudul "Strategi Marketing Public Relations Dalam Rebranding HSBC Indonesia Untuk Membentuk Brand Awareness", penelitian ini juga menunjukkan keberhasilan PR dalam merencanakan proses rebranding hingga akhirnya terbentuk brand awareness publik, yang dilakukan dengan strategi engagement stakegolders. Setelah proses rebranding diterapkan, PR HSBC mulai gencar untuk selalu mengadakan kegiatan sosialisasi dan publikasi menarik bagi nasabah maupun internal perusahaan, serta selalu aktif melibatkan kehadiran media dengan tujuan agar seluruh kegiatan dapat menjadi konten informasi positif mengenai perusahaan untuk di publish kepada khalayak, sehingga akan terbentuk brand awareness dan khalayak semakin memahami isi identitas perusahaan yang baru.

\section{PENUTUP \\ Kesimpulan}

Tujuan dilakukannya rebranding LPP TVRI melalui logo baru, yaitu untuk menunjukkan TVRI sebagai media pemersatu bangsa yang berlandaskan world class public broadcasting, serta untuk mengubah persepsi masyarakat agar tercapai citra TVRI yang positif.

Proses rebranding LPP TVRI melalui logo melibatkan peran semua pihak TVRI termasuk peran bidang Humas, Puslitbang, dan DMID sebagai brand consultant. Dalam proses rebranding ini dilakukan melalui empat tahap. Tahap analyzing diketahui bahwa 
kondisi yang dihadapi TVRI yaitu kurangnya minat penonton karena program TVRI yang monoton dan tidak mampu bersaing. Tahap planning, TVRI merencanakan proses rebranding dengan melibatkan beberapa pihak. TVRI juga menjalankan proses repositioning menjadi media pemersatu bangsa yang multiplatform dan proses re-design logo baru yang bekerja sama dengan brand consultant. Tahap implementation dilakukan dengan menggelar acara launching logo baru TVRI hanya kepada karyawan internal dan beberapa masyarakat yang berkesempatan diundang dalam acara tersebut. Dilanjutkan dengan sosialisasi serta publikasi dengan berbagai media sosial. Tahap evaluation, pada tahap ini belum dilakukan evaluasi secara formal dan keseluruhan.

Dampak proses rebranding LPP TVRI melalui logo baru bagi pihak TVRI merasa proses ini cukup berhasil dengan terbentuknya public trust (kepercayaan publik), dapat merubah citra TVRI menjadi lebih baik dan positif, peningkatan jumlah penonton TVRI, performa TVRI yang semakin membaik, peningkatan rating yang dicapai TVRI, hingga tanggapan publik milenial yang sudah mengetahui adanya proses rebranding melalui logo baru ini. Namun dari sisi penonton merasa bahwa keberhasilan proses rebranding ini masih kurang, sehingga diharapkan adanya perubahan dan perkembangan yang berkelanjutan.

\section{DAFTAR PUSTAKA}

Adianti, Fitria Putri dkk. (2018). Proses Rebranding Mal Grand Indonesia Oleh Departemen Marketing Communication PT Grand Indonesia. Jurnal Ilmiah Ilmu Hubungan Masyarakat, 2(2). http://jurnal.unpad.ac.id/profesihumas/article/view/9063 .

Bantilan, Dini Safitri Istiqomah, dkk. (2017). Strategi Rebranding Zora Radio. Jurnal Ilmiah Ilmu Hubungan Masyarakat, 2 (1). https://doi.org/10.24198/prh.v1i2.12110 .

Febriansyah. Nabila, Nuzul Inas. (2014). Pengaruh Logo Baru PT. Telkom, Tbk Terhadap Citra Perusahaan. Jurnal Ekonomika-bisnis, 5 (2). https://doi.org/10.22219/jibe.v5i2.2262 .

Manzilati, Asfi. (2017). Metodologi Penelitian Kualitatif: Paradigma, Metode, dan Aplikasi. Malang: Universitas Brawijaya Press.

Nurjaman, Kadar. Umam, Khaerul. (2012). Komunikasi \& Public Relations, Bandung: CV Pustaka Setia.

Pasaribu, Ziko. E, Diah Agung. (2015). Pengaruh Penggunaan Media Internal Portal PT Dirgantara Indonesia Terhadap Citra Perusahaan. Jurnal Sosioteknologi, 14 (1). http://dx.doi.org/10.5614\%2Fsostek.itbj.2015.14.1.7.

Priansa, Donni Juni. (2017). Komunikasi Pemasaran Terpadu pada Era Media Sosial. Bandung: CV Pustaka Setia.

Safitri, Dini. (2015). Humas Perusahaan. Jakarta: Lembaga Pengembangan Pendidikan UNJ. 
Santoso, Prasetya Yoga dkk. (2018). Strategi Marketing Public Relations Dalam Rebranding HSBC Indonesia Untuk Membentuk Brand Awareness. Jurnal Pustaka Komunikasi 1 (1). https://doi.org/10.32509/pustakom.v1i1.512 .

Sugianto, Mikael. Community, Smitdev. (2011). Desain Logo Interaktif. Jakarta: PT Elex Media Komputindo. 